\title{
Fertilization success in the commercial gastropod Haliotis tuberculata
}

\author{
Maria C. Baker*, Paul A. Tyler \\ School of Ocean and Earth Science, University of Southampton SOC, Southampton SO14 3ZH, United Kingdom
}

\begin{abstract}
A series of laboratory experiments was conducted to determine fertilization success in the commercial abalone Haliotis tuberculata L. Fertilization success is a function of sperm dilution, sperm-egg ratio, gamete age and the amount of time sperm and eggs are in contact. Sperm density required for optimum fertilization success in vivo, using $10 \mathrm{ml}$ culture volume, was in the range $5 \times$ $10^{4}$ to $5 \times 10^{5}$ sperm $\mathrm{ml}^{-1}$. When these experiments were repeated using $500 \mathrm{ml}$ culture volume, results showed high levels of fertilization success across a far larger range of sperm dilutions with success $>80 \%$ at $10^{3}$ sperm $\mathrm{ml}^{-1}$. Sperm-egg ratios of $>100: 1$ have little effect on fertilization success, but below these levels this factor becomes significant. Viability of both sperm and eggs decreased with age so that no fertilization occurred after $2.5 \mathrm{~h}$. Maximum fertilization success occurred after 30 min sperm-egg contact time. These data suggest that sperm limitation may severely compromise reproductive success in exploited populations of $H$. tuberculata.
\end{abstract}

KEY WORDS: Fertilization success $\cdot$ Abalone $\cdot$ Haliotis tuberculata $\cdot$ Allee effect

\section{INTRODUCTION}

Over-fishing of commercial shellfish stocks has become a major problem over the last 2 decades. There are indications that over-exploitation of some commercial species has led to their extinction (Roberts \& Hawkins 1999). With the decrease in the harvest from shellfisheries, the price of shellfish has risen markedly resulting in even greater pressure on the already depleted stocks. One of the main consequences of overexploitation of fisheries is a reduction in density of stocks. Such density effects were recognised in scallops as long ago as the first decade of the 20th century (Belding 1910), and in oysters before the Second World War (Spärck 1927). Allee (1931) showed that reduction in population density resulted in a disproportionately low recruitment rate. Subsequently, the decreased fertilization success owing to density reduction has been referred to as the 'Allee effect'. If the population density remains too low in an overexploited population,

*E-mail: mb11@soc.soton.ac.uk the individuals present will continue to spawn but will not achieve fertilization and, as a result, will not contribute to the next generation. Experimental analysis of the 'Allee effect' has been conducted primarily in echinoids, although a variety of other free-spawning marine invertebrates have been used in empirical studies of fertilization kinetics (reviewed by Levitan 1995).

There have been few studies of fertilization kinetics centred on commercial free-spawning marine invertebrates (e.g. Clotteau \& Dube 1993, André \& Lindegarth 1995, Styan 1998, Babcock \& Keesing 1999). Clavier (1992) determined the optimum sperm density for fertilization success in the ormer Haliotis tuberculata L. but did not extend the study to further aspects of fertilization kinetics. The most comprehensive study of fertilization kinetics in a commercially valuable freespawning marine invertebrate is for the abalone $H$. laevigata (Babcock \& Keesing 1999).

Amongst free-spawning invertebrates, the gastropod genus Haliotis has been severely over-exploited as it is one of the highest-priced shellfish in the world (Mercer unpubl.). Fisheries for Haliotis exist throughout the world (Fallu 1991) but in European waters the 
only commercially exploited species is $H$. tuberculata. This species has a distribution from the Azores in the west, the Mediterranean in the east, the West African coast in the south and the Channel Islands in the north. The ecology of $H$. tuberculata has been the subject of intense study (Forster 1962, 1967, Hayashi 1980a, Peck 1983, 1989, Peck et al. 1987, Peck \& Culley 1990, Mgaya \& Mercer 1994). H. tuberculata is dioecious and sexes are easily distinguished by examining the large gonad visible from the underside of the shell (Hayashi 1980b). In the Channel Islands, $H$. tuberculata spawns once per year, usually in July, when the water temperature exceeds $16^{\circ} \mathrm{C}$. Under field conditions $H$. tuberculata migrates to high points in the immediate sub-tidal before spawning (L. Peck pers. comm.). Under laboratory conditions, $H$. tuberculata readily spawns, when ripe, with a gentle increase in temperature (R. Tostevin pers. comm.).

In this paper we examine the fertilization kinetics of Haliotis tuberculata from a population in Guernsey, one of the main Channel Islands. The aim of our programme was to determine the fertilization success of this species under controlled conditions that may then be used to determine the minimum density a population must achieve to ensure successful fertilization.

\section{MATERIALS AND METHODS}

General maintenance and procedures. Laboratory experiments were conducted between 28 June and 19 July 1999 and 7 and 15 July 2000 at the Rocquaine Bay Shellfish Ponds, Rocquaine Bay, Guernsey (Channel Islands). Fifteen ripe male and 20 ripe female Haliotis tuberculata were collected each day from Roquaine Bay $\left(49^{\circ} 27^{\prime} \mathrm{N}, 2^{\circ} 40^{\prime} \mathrm{W}\right)$ when the ambient seawater temperature was ca $16^{\circ} \mathrm{C}$. Animals were separated by sex and, following a period of about $30 \mathrm{~min}$ out of water (Genade et al. 1988), were maintained in $30 \mathrm{l}$ plastic tanks with good aeration at a density of 6 to 10 ind. $\operatorname{tank}^{-1}$. Seawater of ambient salinity was used in all experiments. The seawater temperature in the tanks was gradually increased from $17^{\circ} \mathrm{C}$ to a maximum of $21^{\circ} \mathrm{C}$ over a period of 3 to $10 \mathrm{~h}$ in order to induce spawning via thermal stimulus. As spawning commenced, individuals to be used in the experiments were transferred to separate $3 \mathrm{l}$ tanks containing ca $1 \mathrm{l}$ filtered UVirradiated seawater at $20^{\circ} \mathrm{C}$ where they continued to spawn. Preliminary experiments showed that the optimum temperature for speedy, normal larval development lies between 18 and $21^{\circ} \mathrm{C}$. Individuals were allowed to spawn until enough gametes for experiments had been shed. If this took longer than 20 min, gametes were not used. Prior to use, gametes were examined for quality by light microscopy. High quality gametes were obtained when diluted spermatozoa (ca $10^{4} \mathrm{sperm}^{-1}$ ) were highly motile and eggs were of regular shape. After spawning, each experimental animal was weighed wet and shell length was recorded.

Initial sperm concentration for each male was determined by counting 6 replicate sub-samples with a haemocytometer (post-experimentation with the exception of sperm-egg ratio experiments). Egg density was estimated using a Sedgewick Rafter cell. All experimental treatments used 2 to 3 different malefemale pairs with 3 replicates pair ${ }^{-1}$. Egg-only controls were set up in each experiment to test for contamination or parthenogenesis. The percentage of eggs fertilized at each treatment was assessed, using a compound microscope, by the presence of normal or abnormal cleavage in 100 undamaged eggs that were randomly sampled from each treatment at least $4 \mathrm{~h}$ after initial fertilization. After this time, most embryos had reached the 16-cell stage. Both normal and abnormally developing eggs were counted as successfully fertilized, in line with other studies of fertilization success. Abnormal cleavage was quite distinct. Preliminary studies monitored abnormally developing eggs over time and rapid degeneration was seen.

Expt 1: To assess fertilization success at different sperm dilutions. Thirty-three $30 \mathrm{ml}$ sterile glass tubes were rinsed and filled with $8 \mathrm{ml}$ of UV-irradiated, $1.6 \mu \mathrm{m}$-filtered seawater at $19^{\circ} \mathrm{C}$. To each tube $100-$ 200 eggs in $1 \mathrm{ml}$ seawater were then added. Ten 2 -fold dilutions of the most concentrated sperm suspension were prepared. One $\mathrm{ml}$ of each dilution was added to each of 3 tubes containing eggs. Three tubes were left as egg-only controls. Cultures were allowed to develop for at least $4 \mathrm{~h}$ before being examined for fertilization.

Expt 2: To determine the effect of sperm-egg contact time on fertilization success. Sixty-six $30 \mathrm{ml}$ sterile glass tubes were rinsed and filled with $8 \mathrm{ml}$ of UVirradiated, $1.6 \mu \mathrm{m}$-filtered seawater. Strainers, for easy removal of eggs from sperm suspension, were constructed from plastic syringes and $48 \mu \mathrm{m}$ nitex mesh and placed in 33 of the tubes. Sperm was diluted to approximately $10^{5}$ sperm $\mathrm{ml}^{-1}$ based on the results of Expt 1. One $\mathrm{ml}$ of $10^{5}$ sperm ml ${ }^{-1}$ concentration was added to 30 tubes. One $\mathrm{ml}$ of egg suspension was then added to 3 tubes at each sperm dilution for the following periods: $5,30 \mathrm{~s}, 1,2,5,10,30 \mathrm{~min}, 1,2$ and $4 \mathrm{~h}$. Between 100 and 200 eggs ml $\mathrm{ml}^{-1}$ were used in each treatment. The remaining 3 tubes contained eggs only as unfertilized controls. After the experimental gamete contact time, the nitex mesh strainer containing the eggs was removed from each sperm suspension and thoroughly rinsed in fresh filtered seawater to remove excess sperm. After rinsing, eggs were placed into the second set of 33 seawater-filled tubes to allow continued development. 
Expt 3: To determine the effect of sperm-egg ratio on fertilization success. The effect of 3 different sperm-egg ratios on fertilization success was determined using 4 different sperm concentrations. Twelve $30 \mathrm{ml}$ glass tubes, $9 \times 50 \mathrm{ml}$ glass beakers and $18 \times$ $600 \mathrm{ml}$ glass beakers were rinsed with UV-irradiated filtered seawater. Four ml of $1.25 \times 10^{5}$ sperm ml $^{-1}$ concentration were put into three $9 \times 30 \mathrm{ml}$ glass tubes, and 50,500 and 5000 eggs were added to each of these tubes. Fifty $\mathrm{ml}$ of $10^{4}$ sperm ml $\mathrm{m}^{-1}$ concentration were put into nine $50 \mathrm{ml}$ beakers, and 50,500 and 5000 eggs were added to each of 3 of these beakers. Of the $10^{3}$ sperm ml ${ }^{-1}$ concentration, $500 \mathrm{ml}$ were put into $9 \times 600 \mathrm{ml}$ beakers for each dilution, and 50,500 and 5000 eggs were added to each of these beakers. Of the $10^{2}$ sperm ml ${ }^{-1}$ concentration, $500 \mathrm{ml}$ were put into three $9 \times 600 \mathrm{ml}$ beakers, and 50,500 and 5000 eggs were added to each of these beakers. Three $30 \mathrm{ml}$ tubes were used as egg-only controls. Different volume containers are necessary in order to achieve a minimum of 50 eggs treatment ${ }^{-1}$. Egg densities of 50, 500 and 5000 eggs $\mathrm{ml}^{-1}$ were added in order to achieve sperm-egg ratios of $10000: 1,1000: 1$ and 100:1 (1000:1, 100:1 and 10:1 for $10^{2}$ sperm ml ${ }^{-1}$ ). The same culture volumes were used for all ratios at a particular concentration. Cultures were allowed to develop for about $4 \mathrm{~h}$ before examination for fertilization.

As high levels of fertilization success were seen at low sperm densities, Expt 1 was repeated using larger culture volumes of $500 \mathrm{ml}$, but with similar sperm dilutions and number of eggs, in order to further investigate sperm-egg ratio effects upon fertilization success.

Expt 4: To determine the effect of gamete age on fertilization success. The fertilizing capacity of sperm and eggs was assessed against time. Four sperm concentrations $\left(10^{6}, 10^{5}, 10^{4}, 10^{3}\right.$ sperm ml $\left.{ }^{-1}\right)$ were used. The 2 gamete types were aged simultaneously. New fertilizations were conducted every 30 min until fertilization was no longer evident. Eight $\mathrm{ml}$ of filtered seawater was added to $30 \mathrm{ml}$ glass tubes. Every $30 \mathrm{~min}$, $1 \mathrm{ml}$ of sperm of each concentration was added to 3 replicate tubes. One $\mathrm{ml}$ of 100 to 200 eggs $\mathrm{ml}^{-1}$ concentration were added at the same time. Treatments were allowed to develop for ca $4 \mathrm{~h}$.

\section{RESULTS}

\section{Expt 1: Sperm dilution}

The concentration of sperm had an obvious effect on fertilization success of Haliotis tuberculata. Virtually no fertilization occurred at $10^{2}$ sperm $\mathrm{ml}^{-1}$. Fertilization success was ca $20 \%$ at $10^{3}$ sperm ml $^{-1}$. At higher sperm concentrations fertilization success increased rapidly to reach a maximum (ca $100 \%$ ) within a range of $5 \times$ $10^{4}$ to $5 \times 10^{5}$ sperm $\mathrm{ml}^{-1}$ (Fig. 1A). At sperm concentrations $>10^{6}$ sperm $\mathrm{ml}^{-1}$, fertilization success declined, probably as a function of polyspermy. These zygotes were allowed to develop and a substantial increase in abnormal development was observed at these elevated sperm concentrations (Fig. 1B).

\section{Expt 2: Sperm-egg contact time}

Fertilization success was affected by variation in sperm-egg contact time (Fig. 2). Even after $5 \mathrm{~s}$ there was between 15 and $45 \%$ fertilization. At 60 s fertilization success had increased to $>60 \%$ in 2 of the 3 replicates. In Replicates 1 and 2, fertilization success remained relatively constant for $30 \mathrm{~min}$ whilst in Replicate 3 a sharp increase in fertilization success was seen between 5 and 30 min (Fig. 2). Maximum fertilization success occurred after 60 min contact time. At sperm-egg contact times of $>5 \mathrm{~min}$, all treatments showed high fertilization success in excess of $60 \%$.
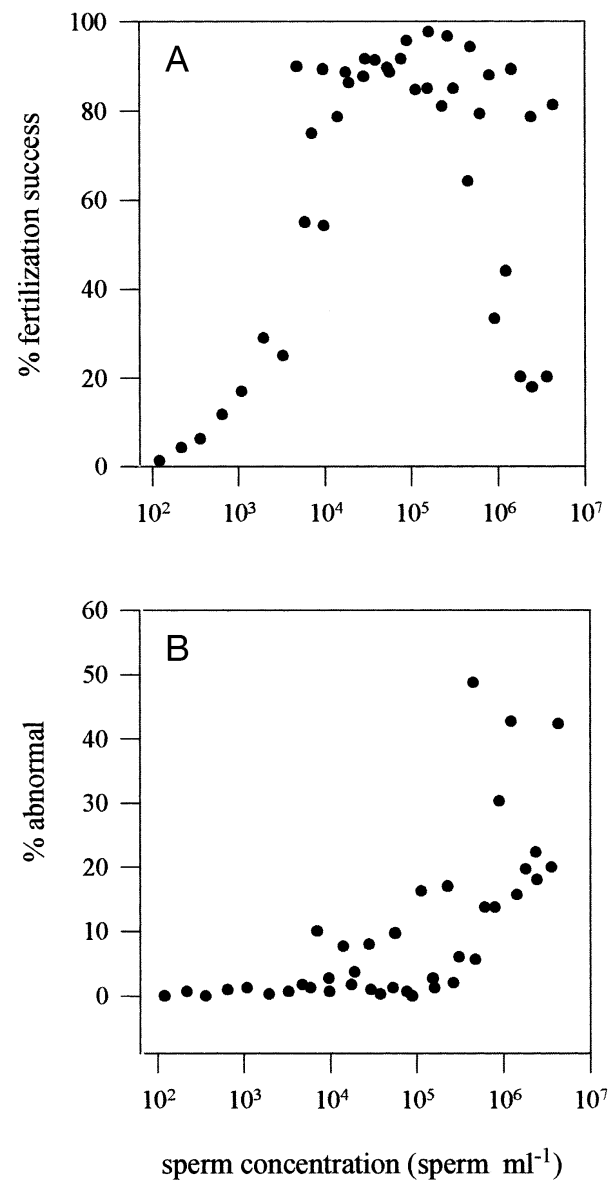

Fig. 1. Expt 1: Haliotis tuberculata. Effect of sperm dilution upon (A) \% fertilization success, (B) \% abnormal development of embryos in $10 \mathrm{ml}$ culture volume 


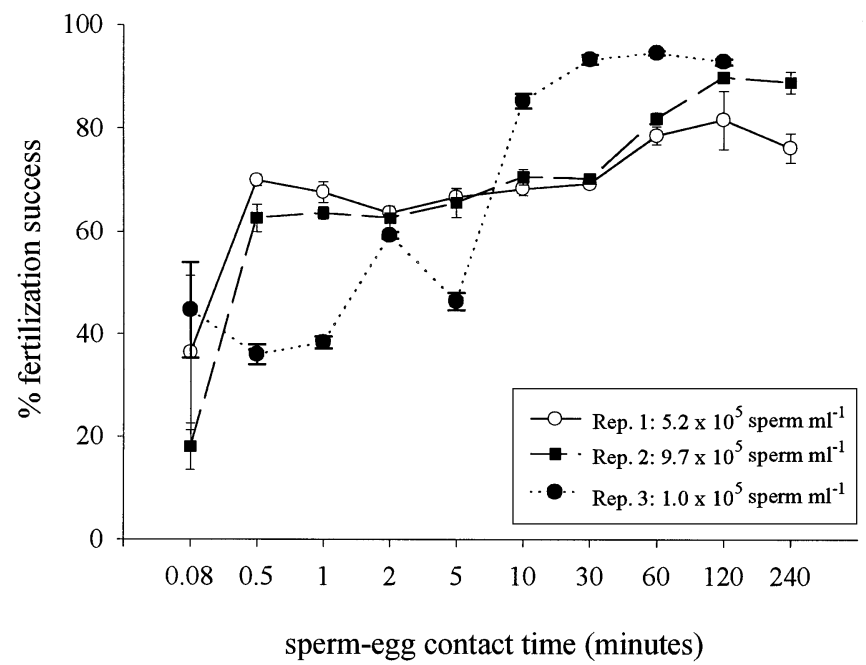

Fig. 2. Expt 2: Haliotis tuberculata. Effect of sperm-egg contact time upon fertilization success. Bars show SE between counts from 3 replicate vials

\section{Expt 3: Sperm-egg ratio}

Fertilization success generally remained high at each sperm-egg ratio and at each different sperm concentration with all treatments resulting in $>58 \%$ fertilization success (Fig. 3). These data suggest no deleterious effect of sperm-egg ratio upon fertilization success, but a clear underlying effect of sperm concentration on the results. At higher sperm concentrations, fertilization success was the highest, decreasing to the lowest value of $58 \%$ at the lowest sperm concentration of $10^{2}$ sperm $\mathrm{ml}^{-1}$ and the lowest sperm-egg ratio of 10:1. Results from the $500 \mathrm{ml}$ culture volume sperm dilution experiment showed that, in contrast to Expt 1, the effect of sperm concentration in these larger volumes had little effect on fertilization success, with high values found from sperm dilutions ranging from $10^{3}$ to $10^{6}$ sperm ml-1 (Fig. 4). Only at the highest sperm concentrations was some detrimental effect seen in the form of polyspermy. At $10^{3}$ sperm $\mathrm{ml}^{-1}$ the sperm-egg ratio was 1000:1 in the larger culture volumes, compared to only $45: 1$ in the $10 \mathrm{ml}$ culture volume.

\section{Expt 4: Gamete age}

Both sperm and eggs were aged simultaneously in these experiments, as would happen in the field assuming synchronous spawning. The more concentrated the sperm suspension, the longer lasting its capacity for fertilization (Fig. 5). Maximum fertilization success occurred with newly released gametes. Fertilization success decreased rapidly within $30 \mathrm{~min}$ of gamete release.
In most cases, fertilization success was $<20 \% 60$ min after the gametes were spawned. In all replicates, the higher sperm concentrations had sperm with a greater longevity (Fig. 5). Some gametes remained capable of successful fertilization $120 \mathrm{~min}$ after release, but by $150 \mathrm{~min}$ there was only successful fertilization at the highest sperm concentration. At the lowest sperm concentrations, sperm and eggs remained capable of fertilization for a maximum of $60 \mathrm{~min}$.

In an uncontrolled experiment, fresh sperm were added to eggs 120 and $150 \mathrm{~min}$ after they were spawned. Fertilization success was low suggesting that ageing eggs, as well as sperm, were having a negative effect on fertilization success.

\section{DISCUSSION}

In Haliotis tuberculata, increasing sperm concentration increases fertilization success up to sperm concentrations of $10^{6}$ sperm $\mathrm{ml}^{-1}$, after which fertilization success declines rapidly. The low fertilization success seen
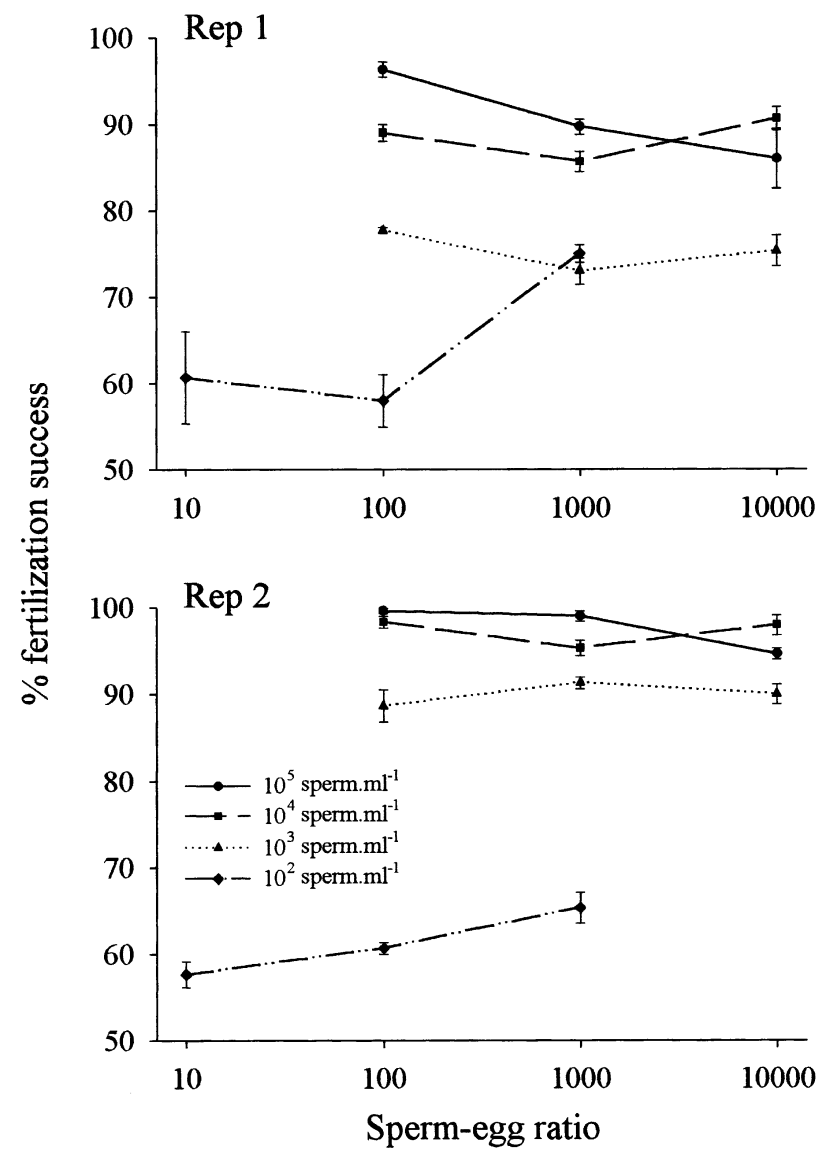

Fig. 3. Expt 3: Haliotis tuberculata. Effect of sperm-egg ratio upon fertilization success. Bars show SE between counts from 3 replicate vials 




Fig. 4. Expt 4: Haliotis tuberculata. Effect of sperm dilution upon fertilization success in $500 \mathrm{ml}$ culture volume. Bars show SE between counts from 3 separate male-female pairings

at low sperm concentrations is a function of the decreased probability of successful egg-sperm encounters. Kikuchi \& Uki (1974) determined a range of suitable sperm concentrations that would achieve $100 \%$ fertilization success in hatchery-spawned $H$. discus hannai. They proposed concentrations of $10^{5}$ to $1.73 \times 10^{6}$ sperm ml ${ }^{-1}$, with $2 \times 10^{5}$ sperm $\mathrm{ml}^{-1}$ being the optimum. This is a similar range to that found for $H$. tuberculata. In the Californian coastal species $H$. rufescens, $H$. corrugata, $H$. fulgens and $H$. sorenseni, Leighton \& Lewis (1982) demonstrated that the concentration of spermatozoa that yielded maximum fertilization with least abnormality in subsequent development was ca $10^{6}$ sperm $\mathrm{ml}^{-1}$. The production of hybrid zygotes from these 4 species required an optimum sperm concentration of $10^{7}$ sperm ml ${ }^{-1}$. Leighton \& Lewis (1982) also found that at sperm concentrations $>10^{8}$ sperm $\mathrm{ml}^{-1}$, lysis of the vitelline layer occurred. Clavier (1992) found a variable optimum sperm concentration when examining fertilization success in $H$. tuberculata in $10 \mathrm{ml}$ culture volume. Optimum sperm concentrations for 10 different species of Haliotis are known (Table 1).

The quality of the eggs produced at spawning is important to subsequent developmental success. Paulet et al. (1992) found variable oocyte quality in Pecten maximus with respect to environmental conditions, especially temperature, during maturation. To eliminate this variability, we analysed only data from individuals that produced $>75 \%$ fertilization success at the optimum sperm concentration. Results for the upper range of sperm concentrations beyond $10^{6}$ sperm $\mathrm{ml}^{-1}$ qualify Clavier's (1992) observations of vitalline layer lysis and ova destruction or abnormal development.
Clavier did not score abnormal development. We believe the abnormally developed larvae scored in the present study were a result of polyspermy as abnormalities increased with increasing sperm concentrations. When several spermatozoa enter an egg, either cell death or abnormalities result during the subsequent embryonic development. Polyspermy may occur during the finite time delay between initial egg fertilization and any polyspermy block activation and is increasingly likely in more concentrated sperm suspensions (Styan 1988). Blocks to polyspermy are common to many taxa (reviewed by Jaffe \& Gould 1985, Togo et al. 1995), but it remains unresolved whether such anti-polyspermy mechanisms exist in the abalone. It is also unknown whether gametic chemotaxis

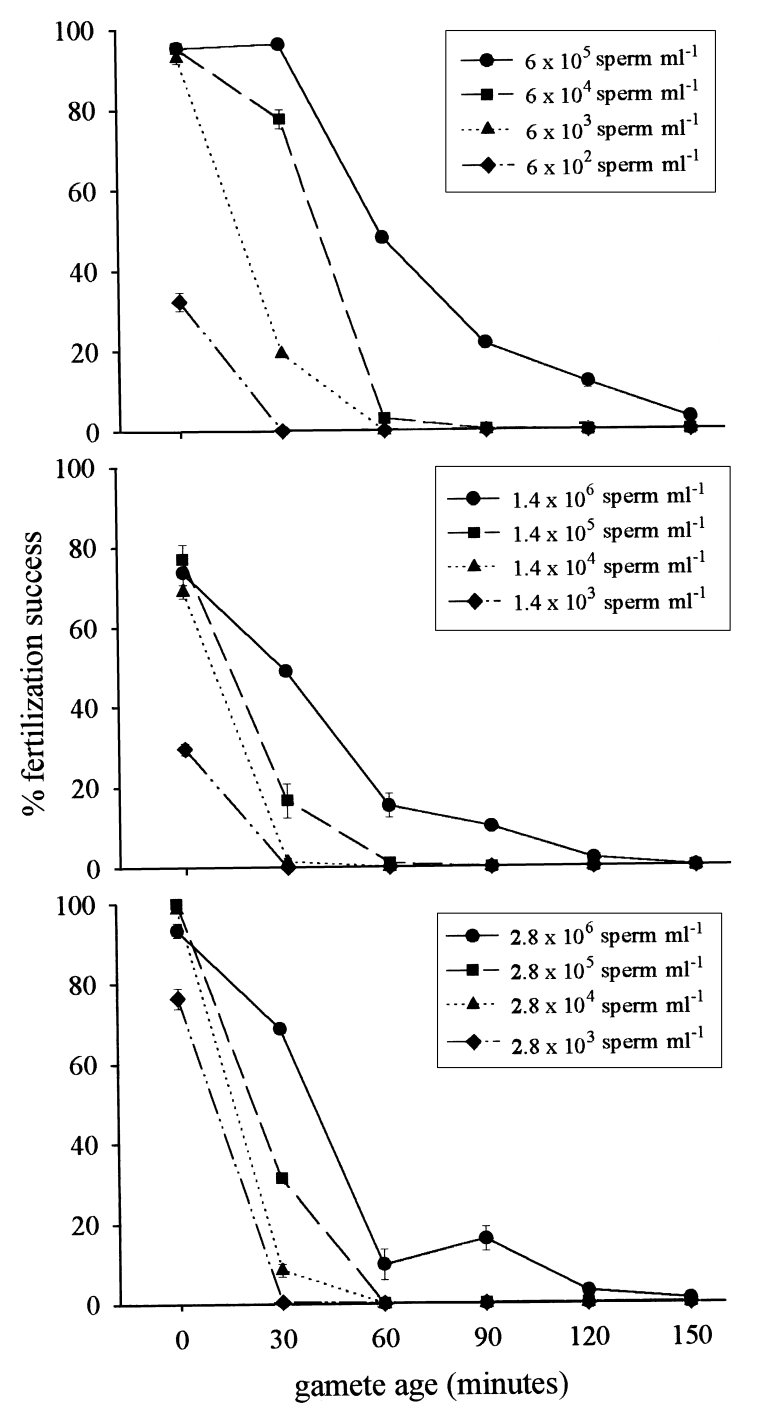

Fig. 5. Expt 5: Haliotis tuberculata. Effect of gamete age upon fertilization success. Bars show SE between counts from 3 replicate vials 
Table 1. Concentration of sperm required to achieve maximum fertilization success in species of Haliotis

\begin{tabular}{|c|c|c|}
\hline Species & $\begin{array}{l}\text { Optimum sperm concentration for } \\
\text { ca } 100 \% \text { fertilization success }\end{array}$ & Source \\
\hline H. tuberculata & $10^{5}$ sperm ml $^{-1}, 10^{5}-10^{6}$ sperm ml ${ }^{-1}$ & This paper, Clavier (1992) \\
\hline H.discus hannai & $2 \times 10^{5}$ sperm ml ${ }^{-1}, 10^{5}-10^{6} \mathrm{sperm} \mathrm{m}^{-1}$ & Kikuchi \& Uki (1974), Gao et al. (1990) \\
\hline H. rufescens & $10^{6} \mathrm{sperm} \mathrm{ml}^{-1}, 10^{5} \mathrm{sperm} \mathrm{ml}^{-1}$ & Leighton \& Lewis (1982), Mill \& McCormick (1989) \\
\hline H. corrugata & $10^{6}$ sperm ml $^{-1}, 10^{5}$ sperm ml $^{-1}$ & Leighton \& Lewis (1982), Mill \& McCormick (1989) \\
\hline H. fulgens & $10^{6}$ sperm ml $^{-1}, 10^{5}$ sperm ml $^{-1}$ & Leighton \& Lewis (1982), Mill \& McCormick (1989) \\
\hline H. sorenseni & $10^{6}$ sperm ml $^{-1}$ & Leighton \& Lewis (1982) \\
\hline H. diversicolor & $2 \times 10^{4}$ sperm ml $^{-1}$ & Fallu (1991) \\
\hline H. laevigata & $2 \times 10^{5}$ sperm ml ${ }^{-1}, 10^{4}-10^{6}$ sperm ml $^{-1}$ & Fallu (1991), Babcock \& Keesing (1999) \\
\hline H. asinina & $5 \times 10^{3}-10^{5}$ sperm ml $^{-1}$ & Encena et al. (1998) \\
\hline H. rubra & $2 \times 10^{5}$ sperm ml $\mathbf{~}^{-1}$ & Fallu (1991) \\
\hline
\end{tabular}

occurs in the abalone. In some species, chemotaxis is thought to increase sperm-egg collision (Miller 1989). By both repelling excess sperm by using blocks to polyspermy and attracting rare sperm using chemotactic mechanisms, individuals can ensure that a maximum number of eggs are fertilized and develop normally under a range of sperm concentrations that will change during each spawning. Oliver \& Babcock (1992) suggested that the pronounced decrease in fertilization success seen with high sperm concentrations may be a function of the combined influences of decreased oxygen, increased $\mathrm{CO}_{2}$ and lower $\mathrm{pH}$. Inactivity of echinoid and ascidian sperm under similar conditions is well documented (Chia \& Bickell 1983).

The length of time eggs remain in contact with a sperm suspension influences the fertilization success of Haliotis tuberculata. The most significant changes in fertilization success occurred in the first few minutes after adding sperm to eggs. Although relatively high sperm concentrations were used in these experiments to eliminate the effect of short-lived sperm at low concentrations, it is possible that at a lower sperm concentration some gamete ageing effects would be evident sooner. Gamete age experiments show a sharp fall in fertilization success within the first 30 min post-spawning for sperm at concentrations of ca $10^{4}$ sperm $\mathrm{ml}^{-1}$. Gamete age must have some effect upon the spermegg contact time results, as ageing effects come into play prior to the sperm-egg contact time resulting in a maximum fertilization success asymptote at 30 to $60 \mathrm{~min}$. Nevertheless, our data indicate that eggs need to be in contact with sperm for several minutes in order to achieve high fertilization success. Similar results were found for the echinoid Strongylocentrotus purpuratus (Levitan et al. 1991) and for the polychaete Nereis virens, the asteroid Asterias rubens and the echinoid Echinus esculentus (Williams 1999). Babcock \& Keesing (1999) found no significant effect of contact time on fertilization success and concluded that a rapid attachment of sperm to eggs occurred in H. laevigata. Ebert \& Houk (1984) found that excess sperm were not detrimental to fertilization success in H. rufescens, provided the excess was removed within 15 to $30 \mathrm{~min}$ post-fertilization.

The sperm-egg ratios of 10000:1, 1000:1 and 100:1 had little overall influence on fertilization success in Haliotis tuberculata with levels of fertilization remaining high. However, when examining sperm dilution effects in smaller volumes, the reduced fertilization success at lower dilutions of $10^{3}$ and $10^{2}$ sperm $\mathrm{ml}^{-1}$ may be a function of sperm-egg ratios of $<100: 1$. For example, ratios of 45:1 obtained in Expt 1 with $10^{2}$ sperm $\mathrm{ml}^{-1}$ dilution may well have the effect of lowering the fertililization success in $H$. tuberculata. A further factor should be considered for the higher fertilization success seen at $10^{3}$ sperm $\mathrm{ml}^{-1}$ in the larger culture volumes. Oocyte dispersal in a larger volume increases the number of potential sperm-egg interactions that may occur prior to the eggs sinking to the bottom of the culture vessel, compared to oocyte dispersal in a $10 \mathrm{ml}$ volume. Provided that the sperm-egg ratio remains above 100:1, in larger volumes, the sperm may be far more dilute but still achieve relatively high fertilization success. Levitan et al. (1991) found similar results to those presented here with little effect of sperm-egg ratio except at the lowest sperm concentrations with highest egg concentrations in the sea urchin Strongylocentrotus franciscanus. They suggested that eggs are usually so rapidly dispersed in the field that only immediately following release from the female would the concentration be sufficient to affect fertilization success. Benzie \& Dixon (1994) reached similar conclusions to Levitan et al. (1991), in that the influence of sperm-egg ratio was shown to only be significant in the first few moments of egg release in Acanthaster planci. Clotteau \& Dube (1993) investigated effects of sperm-egg ratio upon fertilization success in the surf clam Spisula solidissima, and found that ratios 
$>500: 1$ induced increased polyspermic fertilizations, while at ratios <30:1 oocytes remained unfertilized. Good percentages of monospermic fertilizations (80\%) were nevertheless obtained at sperm-egg ratios between 30:1 to 500:1. Results from the present study may suggest that the sex ratio of a population of $H$. tuberculata has little implication for overall fertilization success. However, a severe reduction in either sex would certainly limit reproductive success.

Lillie (1915) recognised the limited life span of gametes. Since then, quantification of gamete age in free-spawning marine invertebrates has spanned a number of different invertebrate groups. Sperm longevity in Haliotis tuberculata is comparable to that of other taxa (Table 2). Table 2 compares similar sperm concentrations with respect to ageing effects as sperm age is known to vary considerably with concentration. The longevity of sperm is extended when sperm are stored at high concentrations. This may be a function of the 'Respiratory Dilution Effect' reviewed by Chia \& Bickell (1983) or simply that more viable sperm (in absolute numbers) will be present at a given time in the denser suspensions.

In the natural environment, high concentrations of abalone sperm would soon be diluted and hence the life span of the sperm would be drastically shortened. Results from the present study are similar to those from gamete age in the tropical abalone Haliotis asinina (Encena et al. 1998) and H. laevigata (Babcock \& Keesing 1999) (Table 2). Oocytes of free-spawning invertebrates usually live longer than the sperm (Pennington 1985). Oocyte longevity in $H$. tuberculata appears to be shorter than previously reported for other invertebrate species. An uncontrolled experiment that examined the longevity of oocytes of $H$. tuberculata indicated that they were ageing at approximately the same rate as the sperm. Male $H$. tuberculata release sperm into the water column slightly ahead of the females releasing their eggs (pers. obs.). The delay of spawning by females may be an adaptation to ensure that sperm are already in the surrounding water during egg release. There is little need for increased longevity in eggs, as the chances are that sperm will already be available when eggs are spawned. Gamete age is not considered to be important in wild populations of free-spawning invertebrates, as the dilution of gametes below fertilizable concentrations would normally occur long before the viable life of gametes has expired. In some situations, however, gamete age could be a factor. For example, if $H$. tuberculata spawn in a tidal pool or some other sheltered water environment, the dilution effect would be lessened and gamete age may increase in significance. The short life-span of $H$. tuberculata sperm may suggest a lack of chemotactic response in gametes of this genus. If chemotaxis were to play a significant role in increasing fertilization success, it would be of great benefit for the gametes to remain viable for longer.

Haliotis tuberculata grow slowly and therefore it is easy to over-harvest this resource (Clavier \& Chardy 1989). Clavier (1992) determined fecundity in relation to body size. The total number of mature oocytes contained in the ovaries was estimated by weighing and dissecting the gonad and counting eggs from sub-samples of gonad. Potential fecundity ranged from $4 \times 10^{5}$ for $20 \mathrm{~g}$ total weight $H$. tuberculata to $8 \times 10^{6}$ for $160 \mathrm{~g}$. This variation in fecundity with size could have a real effect upon the fertilization potential of a population depending upon the adult sizes within that population. As the largest specimens are likely to be harvested first, the reduction in fertilization success caused by a reduction in population density is exacerbated by the lowered fecundity of smaller individuals left in the population after exploitation.

Many examples of stock failure in species of abalone have been reported (Dugan \& Davis 1993, Roberts \&

Table 2. Sperm longevity in a variety of free-spawning marine organisms

\begin{tabular}{|c|c|c|c|}
\hline Species & $\begin{array}{l}\text { Max. sperm } \\
\text { longevity (h) }\end{array}$ & Sperm concentration & Source \\
\hline Strongylocentrotus droebachiensis (sea urchin) & 0.3 & $10^{6}$ sperm ml $l^{-1}$ & Pennington (1985) \\
\hline S. franciscanus (sea urchin) & 2.5 & $10^{6}$ sperm ml $^{-1}$ & Levitan et al. (1991) \\
\hline Ascidia mentula (ascidian) & 48 & Not stated & Havenhand (1991) \\
\hline Arenicola marina (polychaete) & $\sim 85$ & $2.5 \times 10^{5}$ sperm $\mathrm{ml}^{-1}$ & Williams (1999) \\
\hline Nereis virens (polychaete) & $\sim 24$ & $2.5 \times 10^{5}$ sperm ml $^{-1}$ & Williams (1999) \\
\hline Asterias rubens (sea star) & 24 & $2.5 \times 10^{5}$ sperm ml $^{-1}$ & Williams (1999) \\
\hline Acanthaster planci (sea star) & 7 & $10^{5}{\text { sperm } \mathrm{m}^{-1}}$ & Benzie \& Dixon (1994) \\
\hline Cerastoderma edule (bivalve) & $4-8$ & $10^{5}$ sperm ml ${ }^{-1}$ & André \& Lindegarth (1995) \\
\hline Mytilus edulis (bivalve) & $5+$ & $10^{6}$ sperm ml $^{-1}$ & Levy \& Couturier (1996) \\
\hline Platygyra sinensis (coral) & $\sim 5$ & $10^{5}$ sperm ml $^{-1}$ & Oliver \& Babcock (1992) \\
\hline Haliotis asinina (gastropod) & $2+$ & $10^{5}$ sperm ml ${ }^{-1}$ & Encena et al. (1998) \\
\hline H. tuberculata (gastropod) & 2.5 & $10^{6}$ sperm ml $^{-1}$ & This paper \\
\hline
\end{tabular}


Hawkins 1999). Serious consideration should be given to the use of harvest refugia as a management tool for the abalone fishery to provide centres of replenishment for neighbouring harvest zones. Refugias may be more effective than traditional management techniques of size limits and catch quotas, as they preserve natural size distributions and optimise densities. Carefully managed refugias could enhance fishery yields whilst protecting the rather sensitive reproductive potential of these shellfish. Harvest refugia design should be based upon experimental evidence such as that presented here, incorporating consequences of sperm limitation, gamete longevity and population density rather than the usual untested approach (see Dugan \& Davis 1993). If minimum stocking densities to achieve maximum fertilization success are calculated, along with other biological and environmental parameters, these important spawning stocks may be preserved and will provide new recruits to enhance, restore or stabilise abalone yields.

Acknowledgements. Our sincere thanks to Richard \& Pam Tostevin and Lus Lopez for their help and hospitality in Guernsey. We would also like to thank the Guernsey Sea Fisheries Authority for granting permission to collect ormer from Rocquaine Bay for use in these experiments. Thank you also to Dr Sue Utting and Peter Millican of the Conway CEFAS Laboratory for their help and advice during the early stages of method development. The helpful comments from 3 anonymous reviewers of this manuscript were very much appreciated. This work was funded by a NERC studentship GT04/97/271/MAS to M.C.B.

\section{LITERATURE CITED}

Allee WC (1931) Animal aggregations: a study in general sociology. University of Chicago Press, Chicago

André C, Lindegarth M (1995) Fertilization efficiency and gamete viability of a sessile, free-spawning bivalve Cerastoderma edule. Ophelia 43(3):215-227

Babcock RC, Keesing J (1999) Fertilization biology of the abalone Haliotis laevigata: laboratory and field studies. Can J Fish Aquat Sci 56:1668-1678

Belding DL (1910) A report on the scallop fishery of Massachusetts; including the habitats, life history of Pecten irradians, its rate of growth and other factors of economic value. Commonwealth of Massachusetts, Boston

Benzie JAH, Dixon P (1994) The effects of sperm concentration, sperm:egg ratio, and gamete age on fertilization success in Crown-of-Thorns starfish (Acanthaster planci) in the laboratory. Biol Bull Woods Hole 186:139-152

Chia FS, Bickell LR (1983) Spermatogenesis and sperm function. In: Adiyodi KG, Adiyodi RG (eds) Echinodermata. Reproductive biology of invertebrates, Vol 2. John Wiley \& Sons, New York, p 545-620

Clavier J (1992) Fecundity and optimal sperm density for fertilization in the ormer (Haliotis tuberculata L.). In: Shepherd SA, Tegnor MJ, Guzman SA (eds) Abalone of the world. Biology, Fisheries and Culture, Oxford Fishing News Books, London, p 86-92
Clavier J, Chardy P (1989) Investigation into the ecology of the ormer (Haliotis tuberculata L.), factors influencing spatial distribution. Aquat Living Resour 2:191-197

Clotteau G, Dube F (1993) Optimization of fertilization parameters for rearing surf clams (Spisula solidissima). Aquaculture 114(3-4):339-353

Dugan JE, Davis GE (1993) Applications of marine refugia to coastal fisheries management. Can J Fish Aquat Sci 50: 2029-2041

Ebert E, Houk J (1984) Elements and innovations in the cultivation of red abalone Haliotis rufescens. Aquaculture 39: 375-392

Encena VC II, Capinpin EC Jr, Bayona NC (1998) Optimal sperm concentration and time for fertilization of the tropical abalone, Haliotis asinina Linne 1758. Aquaculture 165(3-4):347-352

Fallu R (1991) Abalone farming. Oxford Fishing News Books, London

Forster GR (1962) Observations on the ormer population of Guernsey. J Mar Biol Assoc UK 42:493-498

Forster GR (1967) The growth of Haliotis tuberculata: results of tagging experiments in Guernsey 1963-5. J Mar Biol Assoc UK 47:287-300

Gao X, Liu YF, Liu YX, Lin J (1999) The effect of sperm density of abalone on the egg fertilization rate and the abnormal rate of the fertilized eggs. Trans Oceanol Limnol 3:71-75

Genade AB, Hirst AL, Smith CJ (1988) Observations on the spawning, development and rearing of the South African abalone Haliotis midae Linn. S Afr J Mar Sci 6:3-13

Havenhand JN (1991) Fertilization and the potential for dispersal of gametes and larvae in the solitary ascidian Aacidia mentula Muller. Ophelia 33(1):1-15

Hayashi I (1980a) The reproductive biology of the ormer, Haliotis tuberculata. J Mar Biol Assoc UK 60:415-430

Hayashi I (1980b) Structure and growth of a shore populations of the ormer, Haliotis tuberculata. J Mar Biol Assoc UK 60:431-437

Jaffe LA, Gould M (1985) Polyspermy-preventing mechanisms. In: Metz CB, Monroy A (eds) Biology of fertilization, Vol 3. Academic Press, New York, p 223-250

Kikuchi S, Uki N (1974) Technical study on artificial spawning of abalone, genus Haliotis III. Reasonable sperm density for fertilization. Bull Tohoku Reg Fish Res Lab 34:67-71

Leighton DL, Lewis CA (1982) Experimental hybridization in abalones. Int J Invertebr Reprod 5:273-282

Levitan DR (1995) The ecology of fertilization in free spawning invertebrates. In: McEdward L (ed) Ecology of marine invertebrate larvae. CRC Press, Boca Raton, p 123-156

Levitan DR, Sewell MA, Chia FS (1991) Kinetics of fertilization in the sea urchin Strongylocentrotus franciscanus: interaction of gamete dilution, age and contact time. Biol Bull 181:371-378

Levy LA, Couturier CA (1996) Effects of sperm longevity and gamete concentrations on fertilization success in the blue mussel. Bull Aquacult Assoc Can 96(3):71-73

Lillie FR (1915) Studies of fertilization. VII. Analysis of variations in fertilization power of sperm suspensions in Arbacia. Biol Bull 28:229-251

Mgaya YD, Mercer JP (1994) A review of the biology, ecology, fisheries and mariculture of the European abalone Haliotis tuberculata Linnaeus 1758 (Gastropoda: Haliotidae). Biology and environment. Proc R Ir Acad 94B(3):285-304

Mill TS, McCormick TB (1989) Optimum sperm density for fertilization in three species of abalone (Haliotis). Abalone of the world, biology, fisheries and culture (supplementary papers). Proceedings of the first International symposium on abalone in La Paz, Mexico, 21-25 November 1989 
Miller RL (1989) Evidence for the presence of sexual pheromones in free-spawning starfish. J Exp Mar Biol Ecol 130(3):205-221

Oliver J, Babcock R (1992) Aspects of the fertilization ecology of broadcast spawning corals: sperm dilution effects and in situ measurements of fertilization. Biol Bull 183: 409-417

Paulet YM, Dorange G, Cochard JC, Le Pennec M (1992) Reproduction and recruitment in Pecten maximus (L). Ann Inst Oceanogr 68(1-2):45-64

Peck LS (1983) An investigation into the growth and early development of the ormer, Haliotis tuberculata L. PhD thesis, Portsmouth University, Portsmouth

Peck LS (1989) Feeding, growth and temperature in the ormer, Haliotis tuberculata populations around the coasts of Jersey, Channel Islands. Prog Underw Sci 14:95-107

Peck LS, Culley MB (1990) Structure and density of Haliotis tuberculata populations around the coasts of Jersey, Channel Islands. J Mar Biol Assoc UK 70:67-70

Editorial responsibility: Roger Hughes (Contributing Editor), Bangor, Wales, UK
Peck LS, Culley MB, Helm MM (1987) A laboratory energy budget for the ormer Haliotis tuberculata L. J Exp Mar Biol Ecol 106(2):103-123

Pennington JT (1985) The ecology of fertilization of echinoid eggs: the consequences of sperm dilution, adult aggregation, and synchronous spawning. Biol Bull 169:417-430

Roberts CM, Hawkins JP (1999) Extinction risk in the sea. TREE 14(6):241-246

Spärck R (1927) Studies on the biology of the oyster (Ostrea edulis) III-IV. Rep Dan Biol Stn 33:43-65

Styan C (1998) Polyspermy, egg size, and the fertilization kinetics of free-spawning marine invertebrates. Am Nat 152(2):290-297

Togo T, Osanai K, Morisawa, M (1995) Existence of three mechanisms for blocking polyspermy in oocytes of the mussel Mytilus edulis. Biol Bull 189:330-339

Williams ME (1999) Fertilization ecology of broadcast spawning marine invertebrates. PhD thesis, University of St. Andrews, St. Andrews

Submitted: February 1, 2000; Accepted: August 9, 2000 Proofs received from author(s): January 15, 2001 